\title{
PERFORMANCE OF NOFOSUO, AN ORGANIC FERTILIZER, IN CABBAGE (BRASSICA OLERACEA L.) PRODUCTION IN WEST AFRICA
}

\author{
Pane Jeanne d'Arc Coulibaly ${ }^{1 *}$, Jacques Sawadogo ${ }^{1}$, \\ Augustine Leticia Okoko ${ }^{2}$, Angeline Diarra², Jacqueline Pegdwendé \\ Ouédraogo $^{2}$, Wend-Panga Cédric Ouedraogo ${ }^{2}$, Jean Boukari Legma ${ }^{3}$ \\ ${ }^{1}$ Centre National de la Recherche Scientifique et Technologique, Département de Gestion des \\ Ressources Naturelles et Systèmes de Productions, Laboratoire Sol- Eau Plante. \\ ${ }^{2}$ Institut Polytechnique Privé Shalom (IPS) de Ouagadougou, 11 BP 1435 CMS Ouagadougou 11 - Burkina Faso. \\ ${ }^{3}$ Université Saint - Thomas - d'Aquin (USTA), Faculté des Sciences et Technologies, \\ 06 BP 10212 Ouagadougou 06, Burkina Faso. \\ *Corresponding author: Pane Jeanne d'Arc Coulibaly, Junior Researcher in Soil Science in INERA \\ Kamboinsé, Department of Natural Resources Management/Production Systems \\ DOI: https://doi.org/10.51193/IJAER.2021.7608
}

Received: 01 Dec. 2021 / Accepted: 11 Dec. 2021 / Published: 24 Dec. 2021

\begin{abstract}
This study was carried out in the Northern region of Burkina Faso from 2019 to 2020 to evaluate the agro - economic performance of Nofosuo compost on cabbage yield. The study used a completely randomized Fisher block design to test seven treatments in three replications. The applied treatments were: i) T0 (control), ii) T1 (single Nofosuo compost), iii) T2 (Nofosuo compost + Organic Fertilizer (OF)), iv) T3 (Nofosuo compost + Mineral Fertilizer (MF)), v) T4 (Nofosuo compost + OF + MF), vi) T5 (single OF), vii) T6 (single MF). By this experiment, under Nofosuo compost (T1, T2, T3 and T4), the growth and yield parameters of cabbage were much improved. The study underscored the outperformance of Nofosuo compost combined with organo-mineral fertilizer regardless of the other treatments applied (T0, T5 and T6). T4 was $87.8 \%, 75 \%$ and $71.6 \%$ more improved than T0, T5 and T6 respectively. In addition, it was found that the single Nofosuo compost T1 was the most economically profitable as its value-tocost ratio (14.23) and return on investment (1707.14) were the highest compared to the others. This study would therefore help farmers to decide how to manage this organic fertilizer in their vegetable crop production.
\end{abstract}


International Journal of Agriculture and Environmental Research

ISSN: 2455-6939

Volume: 07, Issue: 06 "November-December 2021"

Keywords: Agro-economic performance, Burkina Faso, cabbage yield, land degradation

\section{INTRODUCTION}

Vegetables are increasingly recognized as essential for food and nutrition security. They are the most abundant source of vitamins, minerals, dietary fiber, and phytochemicals, essential to human health [1] and [2]. Therefore, World Health Organization recommends a minimum intake of $400 \mathrm{~g}$ of vegetables per day to prevent chronic diseases (heart disease, cancers, and diabetes) and provide necessary micronutrients (calcium, iron, iodine, vitamin A, and zinc) to human body [3]. Moreover, vegetable production offers a promising economic opportunity which can reduce rural poverty and unemployment in developing countries [2]. According to this author, it is also a key component of agricultural diversification strategies.

In Francophone countries, fruit and vegetable production increased by more than $50 \%$ in ten years between 2004 and 2014 [4]. According to FAOSTAT [5], about 43 million tons of vegetables are produced in West Africa and are composed by lettuce (Lactuca sativa L.), tomato (Solanum lycospersicum L.), cabbages (Brassica oleracea L.), carrot (Daucus carota L.), African eggplant (Solanum macrocarpon L.), onion (Allium ascalonicum L., Allium cepa L.), bean (Phaseolus vulgaris L.), cucumber (Cucumis sativus L.), etc. [6] and [7]. Cabbage is a nutritious and high-value leafy vegetable widely grown in tropical and temperate regions [8]. The major cabbage-growing countries of the world are South Korea, Germany, Japan, India, South Africa and China.

In Burkina Faso, cabbage is one of the main vegetable crops produced on large areas. The average area cultivated per producer varies from $100 \mathrm{~m} 2$ to $5000 \mathrm{~m} 2$ and an average production of 2,500 m2 generates incomes of 275,000 CFA [9]. However, its production is confronted with numerous constraints. These include high cost of inputs such as pesticides and fertilizers, and attack by pests and diseases. Its production is also threatened by population pressure associated with land scarcity and soil degradation. The cultivated land in Burkina Faso is estimated at around 09 million hectares and about 04 million hectares are currently under cultivation [10]. This situation could be attributed to the severe degradation of land, soil fertility decline, which is generally characterized by a low organic matter content and a lack of phosphorus [11]. This soil fertility decline is a concern for both farmers and researchers who are looking for strategies to increase and maintain soil fertility for intensified agricultural production [12]. One of the strategies for improving soil fertility, particularly in ferrallitic soils that have poor nitrogen and phosphorus contents, is the use of organic fertilizers [13]. Indeed, using organic resouce leads to sustainable land use, which enhances soil properties through soil nutrients availability and reduces soil pollution risks [14]. Conventional farming practices could therefore move towards more sustainable cropping systems, and natural processes should be exploited. This study is then 
conducted to assess the agroeconomic performance of Nofosuo compost in cabbage production. Specifically, it would seek (1) to evaluate the effect of Nofosuo compost on the growth parameters of cabbage, (2) on cabbage yield and yield parameters and (3) to assess its economic profitability on cabbage production.

\section{MATERIAL AND METHOD}

\subsection{Study area}

The experiment was conducted in the Centre - ouest of Burkina Faso, at the BIOPROTECT-B experimental site (Figure 1). The site is located at Soala, at $12^{\circ} 39^{\prime} \mathrm{N}$ and $1^{\circ} 57^{\prime} \mathrm{W}$ (Sawadogo et al., [15]), in an agro climatic zone with rainfall between $700-900 \mathrm{~mm}$. This site has an area of 3 ha and housses diverse activities such as composting, market gardening, cereal production and agricultural product transformation.

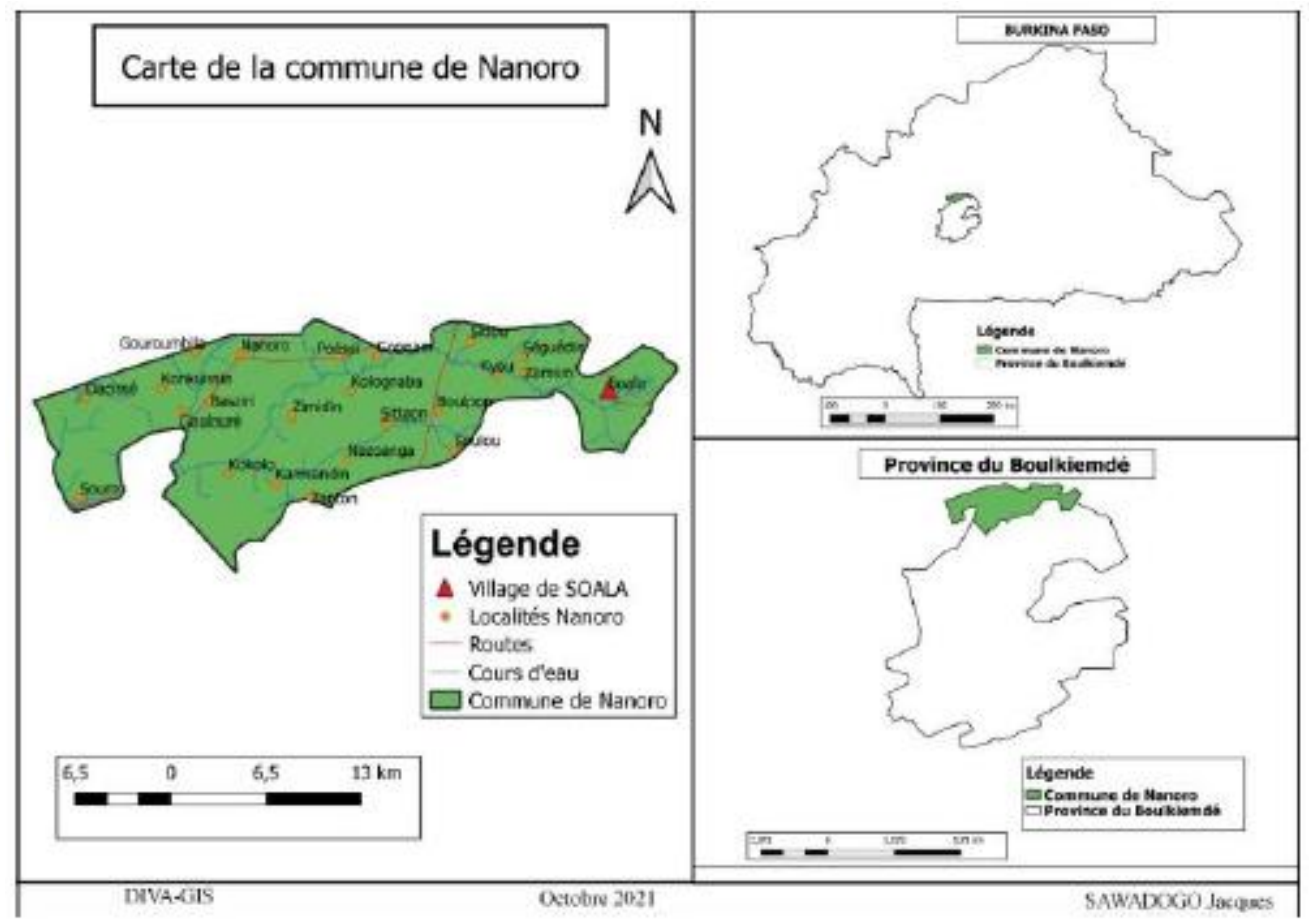

Figure 1: Study area location

\subsection{Experiment design and treatments applied}

The experiment used a completely randomized Fischer Bloc design with 7 treatments in 3 replications. The applied treatments were: T0 (control), (ii) T1 (100 kg/ha of Nofosuo compost), (iii) T2 (100 kg/ha of Nofosuo compost $+30 \mathrm{t} / \mathrm{ha}$ of organic fertilizer), iv) T3 (100 kg/ha of 
International Journal of Agriculture and Environmental Research

ISSN: 2455-6939

Volume: 07, Issue: 06 "November-December 2021"

Nofosuo compost $+550 \mathrm{~kg} / \mathrm{ha}$ of mineral fertilizer), v) T4 (100 kg/ha of Nofosuo compost +30 $\mathrm{t} / \mathrm{ha}$ of organic fertilizer $+550 \mathrm{~kg} / \mathrm{ha}$ of mineral fertilizer), vi) T5 (30 t/ha of organic fertilizer), vii) $\mathrm{T} 6(550 \mathrm{~kg} / \mathrm{ha}$ of mineral fertilizer).

\subsection{Husbandry practices and Data Collection}

A nursery was set up on ground and $5 \mathrm{~g}$ of cabbage seed were sown at the density of $10 \mathrm{~cm} \times 2$ $\mathrm{cm}$. The nursery was then covered with straw and watered regularly. After five days, almost all the plants grew and two weeks after, they were brought to the site to be planted. The planting was done on plots of $2.52 \mathrm{~m}^{2}(1.80 \mathrm{~m} \times 1.40 \mathrm{~m})$ with a spacing of $0.5 \mathrm{~m}$ between plots.

The experimental area was ploughed and harrowed manually three months before planting. Basal applications of Nofosuo compost $(100 \mathrm{~kg} / \mathrm{ha})$ and organic fertilizer $(30 \mathrm{t} / \mathrm{ha})$ were applied to plots to be fertilized with these organic resources. Mineral fertilizers, urea $(50 \mathrm{~kg} / \mathrm{ha})$ and NPK (500 kg/ha), were applied in one and two fractions respectively.

The irrigation was done by watering with watering cans from a dam located near the site.

Weeding was carried out manually two weeks after planting to avoid weed competition and cryptogamic proliferation parasitism.

The biopesticide Piol was used for plants protections. Field data collection consisted of the following operations:

Growth parameters: The concerned parameters were:

- The regrowth rate $(\mathrm{Rr})$ was evaluated at 15 days after planting (DAP) using the formula:

$$
\mathrm{Rr}=\frac{\text { Number of regrown plants }}{\text { Total number of plant hills }} x 100 \text { (1) }
$$

- Plant height was measured with a measuring tape at the $30^{\text {th }}, 40^{\text {th }}, 50^{\text {th }}, 60^{\text {th }}$ DAP;

- Plant diameter was measured with a caliper at the $47^{\text {th }}, 62^{\text {nd }}, 77^{\text {th }}$ and $92^{\text {nd }}$ DAP

Yield and yield components: The yield components studied in this experiment were based on the length and width of cabbage leave measured with a measuring tape at the $50^{\text {th }}$ DAP. To estimate fresh yield, the total numbers of planting hills with well-formed cabbage have been first counted in the area of measurement. Afterwards, cabbage was removed and weighed.

The yield was estimated in kilogram per hectare by dividing their weight by the harvested area and multiplying the product by 10,000 for the extrapolation to the hectare. 


$$
\text { Yield }(\mathrm{kg} / \mathrm{ha})=\frac{\text { Fresh weig ht }(\mathrm{kg}) \times 10000}{\text { area }\left(\mathrm{m}^{2}\right)}
$$

Economic profitability: it was evaluated using two different methods such as

- The value-to-cost ratio (VCR), to identify the best treatment that can be readily adopted by producers.

- The return on investment (ROI), to see whether the profits obtained after the sale of the tomato have made it possible to offset the expenses made during the production.

These two methods respectively were expressed by the following formulas:

$$
\mathrm{VCR}=\frac{\mathrm{X}-\mathrm{Y}}{\mathrm{Z}}
$$

Where $\mathrm{X}$ is the net profit, $\mathrm{Y}$ is the control net profit and $\mathrm{Z}$ is the total variable cost.

$$
\text { ROI }(\%)=\frac{\text { Net profit }- \text { Total variable cost }}{\text { Total variable cost }} \times 100
$$

Delville [16] and Sawadogo et al. [17] concluded a treatment economically profitable if VCR $>2$ and $\mathrm{ROI}>100 \%$.

\section{STATISTICAL ANALYSIS}

To compare variable among treatments, the data were subjected to analysis of variance (ANOVA) using GenStat Release 12.1 software. The means were separated by the NewmanKeuls test at 0.05 of probability level.

\section{RESULTS AND DISCUSSION}

\subsection{Effect of Nofosuo compost on the growth rate of cabbage}

Before starting the experiment, a sample of Nofosuo compost was analysed and this analysis showed a neutral $\mathrm{pH}$ bio-fertilizer with high levels of organic matter, total $\mathrm{N}, \mathrm{P}, \mathrm{K}$, and high level of exchangeable bases (Table 1). 
International Journal of Agriculture and Environmental Research

ISSN: 2455-6939

Volume: 07, Issue: 06 "November-December 2021"

Table 1: Chemical composition of Nofosuo compost

\begin{tabular}{|c|c|c|c|c|c|c|c|c|c|c|c|c|c|}
\hline \multirow[t]{2}{*}{ pH } & OM & Nt & $\mathbf{P t}$ & Kt & $\mathbf{C} / \mathbf{N}$ & Mn & $\mathrm{Cu}$ & $\mathrm{Zn}$ & B & $\mathrm{S}$ & $\mathrm{Ca}$ & Mg & \multirow{2}{*}{$\begin{array}{c}\text { Humidity } \\
\%\end{array}$} \\
\hline & \multicolumn{4}{|c|}{$\%$} & & \multicolumn{7}{|c|}{$\mathrm{mg} / \mathrm{kg}$} & \\
\hline 7.24 & 73.92 & 2.73 & 2.95 & 1.49 & 16 & 189 & 126 & 208 & 228 & 684 & 12.36 & 6.42 & 6.78 \\
\hline
\end{tabular}

Legend: OM: organic matter; Nt: total nitrogen; Pt: total phosphorus; Kt: total potassium; C/N: carbon to nitrogen ratio; Mn: Manganese; Cu: Copper; Zn: Zinc; B: Boron; S: Sulfur; Ca: Calcium; Mg: Magnesium; $\mathrm{pH}$ : hydrogen potential.

The analyse of variance performed on the regrowth rate showed high significant $(p<0,001)$ influence induced by the treatments. Treatments based on Nofosuo compost (T1, T2, T3 and T4) proved to be the best impacting positively the regrowth rate in this experiment. Moreover, Figure 2 revealed that compared to the other treatments based on Nofosuo compost, treatment combining Nofosuo compost with the organic and mineral fertililizers was the most improving the regrowth rate evaluated at $90 \%$. The control treatment (T0) was the less influencing the regrowth rate (38.33\%). The best regrowth rate found in $\mathrm{T} 4$ treatment could be explained by the chemical composition of the soil on which this treatment was applied. Indeed, Nofosuo compost, made by Farmer Hope Company [18] in Ghana, contains a significant amount of organic matter (4.80\%), nitrogen (4.08\%), phosphorus (3.81\%), potassium (3.04\%) and high amount of exchangeable bases necessary to improving soil fertility by providing essential nutrients for the regrowth of cabbage plants and their development.

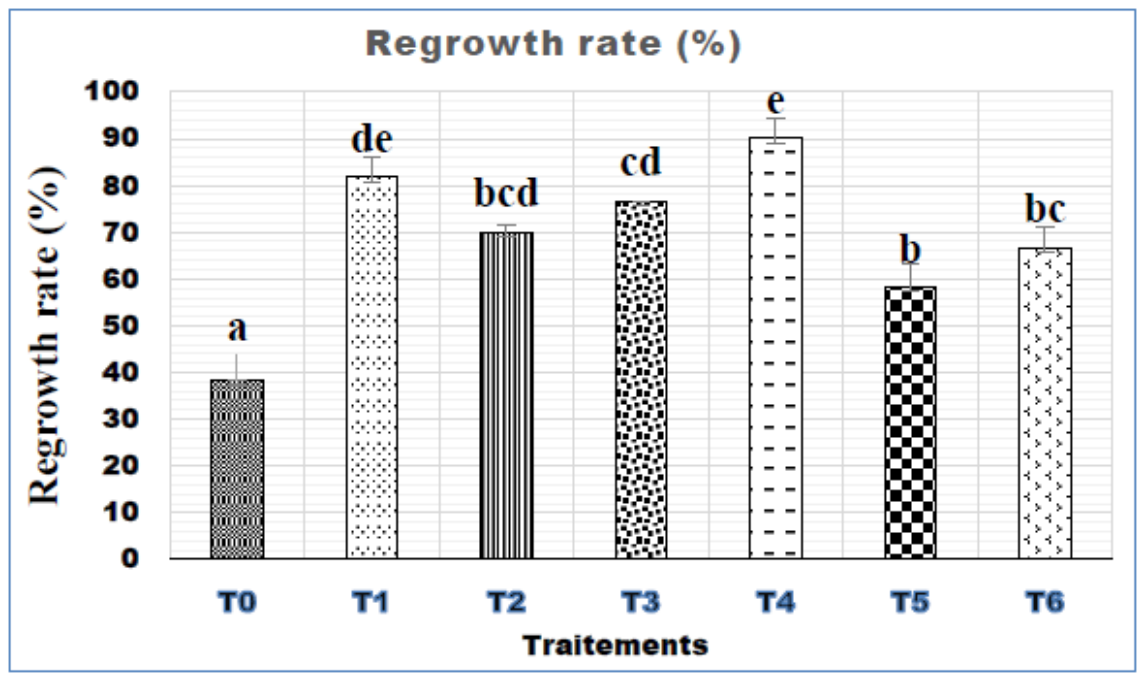

Figure 2: Regrowth rate as affected by treatments 
International Journal of Agriculture and Environmental Research

ISSN: 2455-6939

Volume: 07, Issue: 06 "November-December 2021"

Legend: T0: control, T1: Nofosuo compost, T2: Nofosuo compost + organic fertilizer, T3: Nofosuo compost + mineral fertilizer, T4: Nofosuo compost + organic fertilizer + mineral fertilizer, T4: organic fertilizer, T5: mineral fertilizer, T6: mineral fertilizer; the bars indicate standard errors of means; graphs with the same letters are not significantly different at $5 \%$ of probability.

\subsection{Effect of Nofosuo compost on cabbage plant height, plant diameter, leave length and width}

Data collected on plant height and diameter (Table 2 and Figure 3) and subjected to analysis of variance indicated that all treatments had more or less significant influence on cabbage plant height and diameter.

Regardless plant heigh, at 30 and 40 DAP, a highly significant influence ( $p=0.008$ and $p=0.001$ ) was induced by the applied treatments. The highest heights were recorded in the plots with Nofosuo compost (T1 $(9.7 \mathrm{~cm}$ and $15.8 \mathrm{~cm}), \mathrm{T} 3(9.5 \mathrm{~cm}$ and $15.2 \mathrm{~cm})$ and T4 $(9.9 \mathrm{~cm}$ and 16.7 $\mathrm{cm})$ ) while the lowest height was noted in the control plots T0 $(8.1 \mathrm{~cm}$ and $11.2 \mathrm{~cm})$. From the 50th to the 60th DAP, plants height in the plots remained constant and no significant effect $(p>0.05)$ was noted. However, similarly to the two first periods, treatments with Nofosuo compost (T1, T3 and T4) recorded the highest height.

Concerning plant diameter (Figure 3), the same observations were made. Treatments based on Nofosuo compost (T1, T3 and T4) were the most improving plant diameter. In addition, Nofosuo compost combined with organo-mineral fertilizer (T4) was the fertilizer that contributed to the best cabbage plant growth and development over the entire vegetative period.

Regarding cabbage leave length and width, at 50 DAP, data collected and analyzed underscored significant $(p=0.011)$ and high significant $(p=0.006)$ effect of treatments on leave length and width respectively. Treatments based on Nofosuo compost were found to have the highest leave length and width. Specifically, table 3 presented the lowest leave length $(13.3 \mathrm{~cm})$ and widths $(9.67 \mathrm{~cm})$ in the control treatment while those having highest length $(20.30 \mathrm{~cm})$ and width $(17.28$ $\mathrm{cm}$ ) were observed in Nofosuo compost combined with organo-mineral fertilizer (T4).

These growth parameters improvement due to Nofosuo compost combined with the organomineral fertilizer mighed be explained by its beneficial effect on soil and on these growth parameters. Similar results were reported by several researches. Some of them found that the combined incorporation of organic and mineral fertilizers resulted to the reduction in soil nutrients deficiencies under the exclusive use of mineral fertilizers. The case studied by Chand $e t$ $a l$. [19] on mustard crops highlighted that the combination of the two types of fertilizers led to best soil nutrients uptake and played an important role in maintaining soil fertility and crop 
Volume: 07, Issue: 06 "November-December 2021"

productivity. Dutta et al. [20] also reported that the combined use of organic and mineral fertilizer, compared to organic and mineral fertilizer alone, increases soil fertility, microbial biomass and improves soil health. These results are also in agreement with those of Bokhtiar and Sakurai [21] who showed that the application of organo-mineral fertilizer contributed to increase sugarcane leaf tissue N, P and K uptake more than it was with mineral fertilizer alone. These findings also confirm those of Nacro [22], Sawadogo [23] and Tougouma [24] who indicated the efficiency of organo-mineral fertilizer in improving soil fertility and crop growth more than mineral fertilizer and organic manure applying alone.

Table 2: Cabbage plant height as affected by treatments

\begin{tabular}{cccc}
\hline & \multicolumn{3}{c}{ Plant height (cm) } \\
\hline Treatments & H30 & H40 & H50 and H60 \\
\hline T0 & $8.1^{\mathrm{a}}$ & $11.2^{\mathrm{a}}$ & $16.8^{\mathrm{a}}$ \\
T1 & $9.7^{\mathrm{b}}$ & $15.8^{\mathrm{cd}}$ & $20.6^{\mathrm{ab}}$ \\
T2 & $9.3^{\mathrm{ab}}$ & $14.5^{\mathrm{bcd}}$ & $19.6^{\mathrm{ab}}$ \\
T3 & $9.5^{\mathrm{b}}$ & $15.2^{\mathrm{bcd}}$ & $20.4^{\mathrm{ab}}$ \\
T4 & $9.9^{\mathrm{b}}$ & $16.7^{\mathrm{d}}$ & $22.3^{\mathrm{ab}}$ \\
T5 & $8.6^{\mathrm{ab}}$ & $12.9^{\mathrm{ab}}$ & $18.4^{\mathrm{ab}}$ \\
T6 & $8.8^{\mathrm{ab}}$ & $13.7^{\mathrm{bc}}$ & $18^{\mathrm{b}}$ \\
\hline Cv (\%) & 5.6 & 6.9 & 9.7 \\
\hline Pr. (<0.05) & 0.008 & 0.001 & 0.067 \\
\hline Significance & $\mathrm{HS}$ & $\mathrm{HS}$ & $\mathrm{NS}$ \\
\hline
\end{tabular}

Legend: T0: control, T1: Nofosuo compost, T2: Nofosuo compost+organic fertilizer, T3: Nofosuo compost+mineral fertilizer, T4: Nofosuo compost+organic fertilizer+mineral fertilizer, T4: organic fertilizer, T5: mineral fertilizer, T6: mineral fertilizer; NS: no significant; $C v$ : coefficient of variation; Pr: probability; means with the same letter in the same column are not significantly different at the probability level of 0.05. 
International Journal of Agriculture and Environmental Research

ISSN: 2455-6939

Volume: 07, Issue: 06 "November-December 2021"

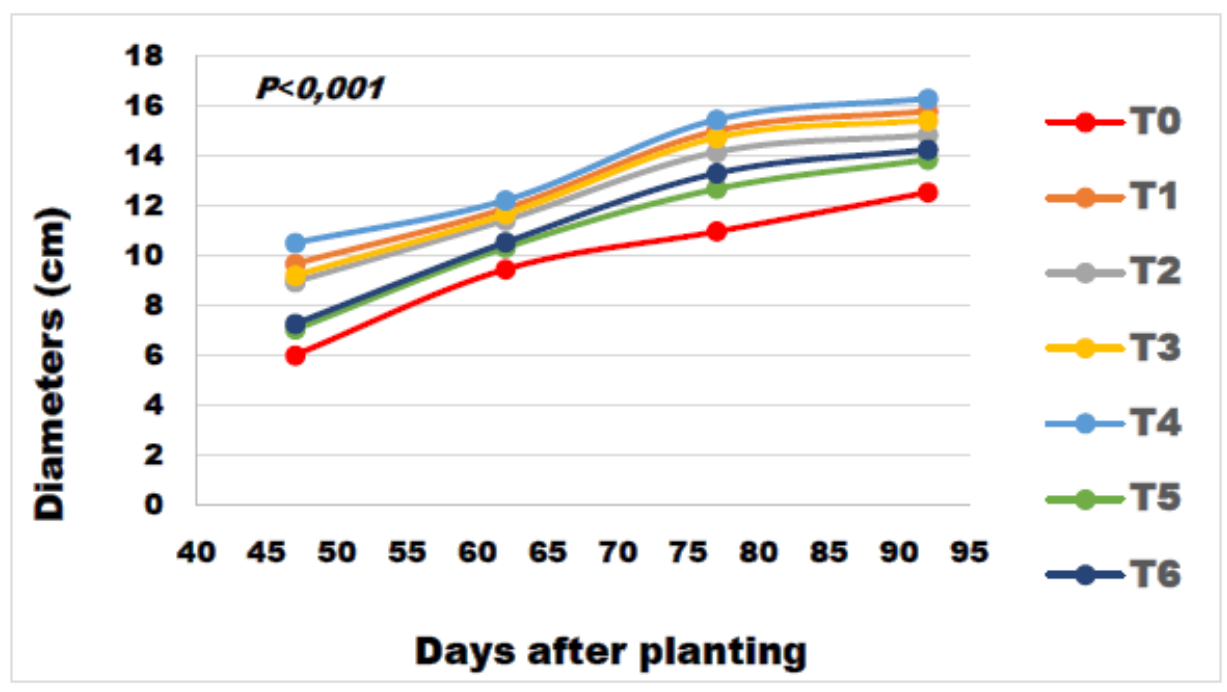

Figure 3: Plant diameters as affected by treatments

Legend: T0: control, T1: Nofosuo compost, T2: Nofosuo compost + organic fertilizer, T3: Nofosuo compost + mineral fertilizer, T4: Nofosuo compost + organic fertilizer + mineral fertilizer, T4: organic fertilizer, T5: mineral fertilizer, T6: mineral fertilizer.

Table 3: cabbage leave length and width as affected by treatments

\begin{tabular}{ccc}
\hline Treatments & Length $(\mathbf{c m})$ & Width $(\mathbf{c m})$ \\
\hline T0 & $13^{\mathrm{a}} \pm 1.431$ & $9.67^{\mathrm{a}} \pm 0.726$ \\
T1 & $17.73^{\mathrm{a}^{\mathrm{b}} \pm 0.274}$ & $16^{\mathrm{b}} \pm 1.059$ \\
T2 & $15.85^{\mathrm{a}} \pm 0.802$ & $14.32^{\mathrm{b}} \pm 1.059$ \\
T3 & $16.78^{\mathrm{ab}} \pm 0.404$ & $15^{\mathrm{b}} \pm 0.764$ \\
T4 & $20.30^{\mathrm{b}} \pm 1.179$ & $17.28^{\mathrm{b}} \pm 1.237$ \\
T5 & $13.95^{\mathrm{a}} \pm 1.750$ & $12.50^{\mathrm{ab}} \pm 1.127$ \\
T6 & $14,30^{\mathrm{a}} \pm 1.513$ & $13.30^{\mathrm{ab}} \pm 1.528$ \\
\hline CV $(\%)$ & 12.7 & 13.6 \\
\hline Pr $\leq 0,05$ & 0.011 & 0.006 \\
\hline Significance & $\mathrm{S}$ & $\mathrm{HS}$ \\
\hline
\end{tabular}

Legend: T0: control, T1: Nofosuo compost, T2: Nofosuo compost+organic fertilizer, T3: Nofosuo compost+mineral fertilizer, T4: Nofosuo compost+organic fertilizer+mineral fertilizer, T4: organic fertilizer, T5: mineral fertilizer, T6: mineral fertilizer; NS: no significant; Cv: 
International Journal of Agriculture and Environmental Research

ISSN: 2455-6939

Volume: 07, Issue: 06 "November-December 2021"

coefficient of variation; Pr: probability; means with the same letter in the same column are not significantly different at the probability level of 0.05 .

\subsection{Effect of Nofosuo compost on cabbage fresh yield}

Cabbage fresh yield assessed at the harvest at 96 DAP and analyzed, showed highly significant $(p<0.001)$ effect of applied treatments. These results showed that, the combination of other fertilizer with Nofosuo compost resulted in better yield improvement than the yield from the Nofosuo compost in single use. We noted that the combination of mineral fertilizer with Nofosuo in single use was more agronomically benefit $(101.9 \mathrm{t} / \mathrm{ha})$ than when organic fertilizer was combined with Nofosuo in single use (94.1 t/ha). The results presented in Figure 4, reported highest yield (133.6 t/ha) when Nofosuo compost was combined with the two fertilizers (organic and mineral fertilizers). Compared to the control treatment $\mathrm{T} 0$, treatment under organic fertilizer (T5) and under mineral fertilizer alone (T6), the Nofosuo compost combined with organic and mineral fertilizers (T4) contributed to the best improvement of cabbage yield. Meaning that T4 was $87.8 \%, 75 \%$ and $71.6 \%$ more improved than $\mathrm{T} 0, \mathrm{~T} 5$ and $\mathrm{T} 6$ respectively. Comparing the effect of Nofosuo compost (in single use) with those of the control, organic and mineral fertilizer (in single use), we realized that $\mathrm{T} 1$ was $82 \%, 66 \%$ and $61.6 \%$ more improved than T0, T5 and T6. These results highlighted the importance of Nofosuo compost in cabbage production. Farmers Hope Company [18], revealed that this organic fertilizer is a high quality organic fertilizer improving soil nutrients. It improves organic crop production and maintains the sustainability of agricultural lands as it is made with crop residues rich in organic matter. According to this Company, Nofosuo resulted in the increase of crops nutritional content in Ghana. This is confirmed in this study as the best yields were obtained in all plots where Nofosuo compost was applied. Moreover, the high yield improvement due to the combination of Nofosuo compost with the organo-mineral fertilizers resulted from the bioavailability of nutrients contained in this bio fertilizer. These results are in accordance with those of Ayinla et al. [25] and Nyembo et al. [26] who reported crop growth and yield enhancement from mineral fertilizers combined with organic matter. These results are also similar to those of Seh [27] and Guiatin [28] who demonstrated that composts in combination with organo-mineral fertilizer significantly improve vegetable crop yield. This experiment also found that Nofosuo compost prevented the occurrence of soil fungal diseases. Therefore, it has some properties leading to microbial health and soil aeration improvement. 


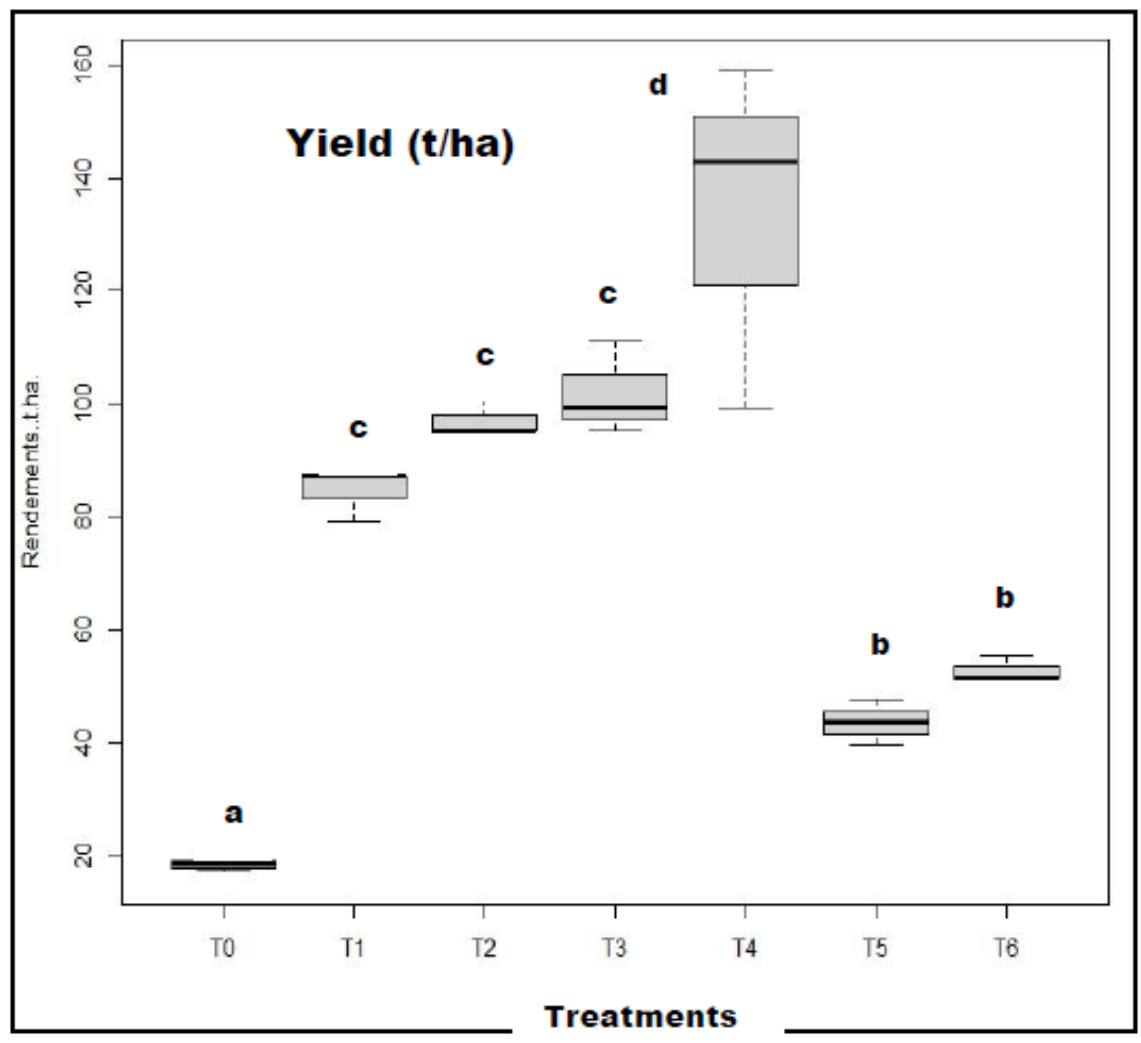

Figure 4: Cabbage fresh yield as affected by treatments

Legend: T0: control, T1: Nofosuo compost, T2: Nofosuo compost + organic fertilizer, T3: Nofosuo compost + mineral fertilizer, T4: Nofosuo compost + organic fertilizer + mineral fertilizer, T4: organic fertilizer, T5: mineral fertilizer, T6: mineral fertilizer; the bars indicate standard errors of means; graphs with the same letters are not significantly different at 5\% of probability.

\subsection{Assessing the economic profitability of Nofosuo compost in cabbage production}

The assessment led to the following conclusion: the highest production costs resulted from the application of Nofosuo compost combined with the two fertilizer T4 (organic and mineral), to its combination with mineral fertilizer (T3) and with organic fertilizer (T2) ; the lowest costs were found in T0, T5 and T6 treatments (Table 4). However, compared to other treatments, the gross profit values were obtained in treatments based on Nofosuo compost (T1, T2, T3 and T4) (Table 4). We realized that the gross profit increased when the combination of fertilizers was important. Consequently, the gross profit of $\mathrm{T} 1<\mathrm{T} 2<\mathrm{T} 3<\mathrm{T} 4$ (Table 4). Although the gross profit was the highest in T4 treatment, the VCR and the ROI estimated showed that Nofosuo compost in single use (T1) had the highest VCR (14.23) and ROI (1,707.14) (Table 4). Economically, it was than 
International Journal of Agriculture and Environmental Research

ISSN: 2455-6939

Volume: 07, Issue: 06 "November-December 2021"

the most profitable treatment. These results asserted those of Kitabala et al. [29] and Mankoussou et al. [30] who found that the use of composts is more profitable than that of mineral fertilizer. They indicated that the use of composts in vegetable crop production covers production costs. And for Delville [16], the treatments based on Nofosuo compost having the VCR superior to 2 and ROI superior to $100 \%$, implies that these treatments, especially the Nofosuo compost in single use, are really attractive as they are profitable.

Table 4: Economic profitability of cabbage as affected by treatmentt (FCFA)

\begin{tabular}{lcllllll}
\hline Treatments & $\begin{array}{l}\text { Total variable } \\
\text { cost (FCFA/ha) }\end{array}$ & $\begin{array}{l}\text { Yield } \\
\text { (kg/ha) }\end{array}$ & $\begin{array}{l}\text { Gross income } \\
\text { (FCFA/ha) }\end{array}$ & $\begin{array}{l}\text { Gross profit } \\
\text { (FCFA/ha) }\end{array}$ & $\begin{array}{l}\text { Net profit } \\
\text { (FCFA/ha) }\end{array}$ & VCR & ROI (\%) \\
\hline T0 & 615,845 & 18,580 & $9,290,000$ & $8,674,155$ & $6,816,155$ & - & $1,006.80$ \\
T1 & $1,775,645$ & 84,660 & $42,330,000$ & $40,554,355$ & $32,088,355$ & 14,23 & $1,707.14$ \\
T2 & $2,212,633$ & 97,090 & $48,545,000$ & $46,332,368$ & $36,623,368$ & 13,47 & $1,555.19$ \\
T3 & $2,259,483$ & 101,850 & $50,925,000$ & $48,665,518$ & $38,480,518$ & 14,01 & $1,603.07$ \\
T4 & $3,074,420$ & 133,600 & $66,800,000$ & $63,725,580$ & $50,365,580$ & 14,17 & $1,538.21$ \\
T5 & $1,297,233$ & 43,650 & $21,825,000$ & $20,527,768$ & $16,162,768$ & 7,21 & $1,145.94$ \\
T6 & $1,417,208$ & 52,910 & $26,455,000$ & $25,037,793$ & $19,746,793$ & 9,12 & $1,293.36$ \\
\hline
\end{tabular}

Legend: T0: control, T1: Nofosuo compost, T2: Nofosuo compost + organic fertilizer, T3: Nofosuo compost + mineral fertilizer, T4: Nofosuo compost + organic fertilizer + mineral fertilizer, T4: organic fertilizer, T5: mineral fertilizer, T6: mineral fertilizer

\section{CONCLUSION}

This study showed the possibility to produce high yield of cabbage using organic fertilizer especially the Nofosuo compost from Farmers Hope Company in Ghana. The study underscored the outperformance of the combination of Nofosuo compost with organo-mineral fertilizers over the other fertilizers such as mineral and organic fertilizers in single use regardless of the management options and growing conditions. This study also demonstrated that the application of Nofosuo compost in single use was very economically profitable as its VCR and ROI were greater than 2 and $100 \%$ respectively. This study has therefore to merit of helping farmers to increase their sources of organic fertilizers and show them how to manage this biofertilizer for yield improvement and soil fertility maintain.

\section{ACKNOWLEDGEMENT}

We are thankful to Mr SAVADOGO Claude Arsène, the Administrator of BIOPROTECT-B for having accepted this study in its field and for diverse support. 
International Journal of Agriculture and Environmental Research

ISSN: 2455-6939

Volume: 07, Issue: 06 "November-December 2021"

\section{REFERENCES}

[1] Asaduzzaman, M.; Asao, T. (2018). Introductory Chapter: Quality Vegetable Production and Human Health Benefits. Open access peer-reviewed chapter, 2-4.

[2] Schreinemachers, P.; Simmons, E.B.; Wopereis, M.C.S. (2018). Tapping the economic and nutritional power of vegetables. Glob. Food Sec., 16, 36-45.

[3] WHO (2015). Promoting Fruit and Vegetable Consumption around the World. World Health Organization, Geneva.

[4] Douet, M. (2017). Agriculture: succès du maraîchage en Afrique francophone. Tiré de « Agriculture: l'Afrique tire son épingle du jeu ».

[5] FAOSTAT (2021). L'État de la sécurité alimentaire et de la nutrition dans le monde 2020.

[6] Mawussi, G.; Júnior, R.P.S.; Dossa, E.L.; Alaté, K.-K.A. (2014). Insecticide residues in soil and water in coastal areas of vegetable production in Togo. Environ. Monit. Assess., 186: 7379-7385.

[7] Zabeirou, H.; Guero, Y.; Tankari, D.B.A.; Haougui, A.; Basso, A. (2018). Farmers practices of pesticide use on market gardening in the department of Madaou, Niger. Environ. Water Sci. Public Health Territ. Intell. J., 2 : 63-74.

[8] Nagdeve, M. (2021). 12 Proven Health Benefits and Uses Of Cabbage, Information sheet.

[9] Chambre Régionale d'Agriculture de Dosso (2017). Fiche technico-économique pour la culture du chou, 1-3.

[10] Compaoré, M.; Kabore, K. B. (2017). Rapport national sur l'état des ressources phytogénetiques pour l'alimentation et l'agriculture, Burkina Faso 45 pages.

[11] FAO (2001). Etude opérationnelle sur la filière des intrants au Burkina Faso, rapport définitif, 296 pages.

[12] Saïdou, A.; Kossou, D.; Azontondé, A.; Hougni, D.-G.J.M. (2009). Effet de la nature de la jachère sur la colonization de la culture subséquente par les champignons endomycorhyziens: cas du système 'jachère' manioc sur sols ferrugineux tropicaux du Bénin, Int. J. Biol. Chem. Sci., 3(3): 587-597.

[13] Koné, B.; Diatta, S.; Saïdou, A.; Akintayo, I.; Cissé B. (2009). Réponses des variétés interspécifiques du riz de plateau aux applications de phosphate en zone de forêt au Nigeria, Can. J. Soil Sci., $89: 555-565$.

[14] Biaou, O.D.B.; Saidou, A.; Bachabi, F-X.; Padonou, G.E.; Balogoun, I. (2017). «Effet de l'apport de différents types d'engrais organiques sur la fertilité du sol et la production de la carotte (Daucus carota L.) sur sol ferralitique au sud Bénin »Int. J. Biol. Chem. Sci., $11(5): 2315-2326$. 
International Journal of Agriculture and Environmental Research

ISSN: 2455-6939

Volume: 07, Issue: 06 "November-December 2021"

[15] Sawadogo, J.; Ouédraogo, W.B.M.; Coulibaly, P.J.A.; Savadogo, C.A.; Kaboré, A.; Legma J.B. (2019). «Étude comparative de la qualité de trois amendements organobiologiques sur la production de tomate à Soala dans le Centre-Ouest du Burkina Faso », Science Technique : SNA, 38(1) : 35-50.

[16] Delville, P.L. (1996). Gérer la fertilité des terres dans les pays du sahel : Diagnostic et conseil aux paysans, Collection le point sur, 97 pages.

[17] Sawadogo J., Coulibaly P.J.A., Traore B., Bassolé M.S.D., Savadogo C.A., Legma J.B. (2021). Effets des fertilisants biologiques sur la productivité de la tomate en zone semiaride du Burkina Faso. J. Appl. Biosci., 167 : 17375 -17390.

[18] Farmers Hope C. L., (2017). Fiche technique de Nofouo, 1 page.

[19] Chand, S.; Anwar, M.; Patra, D. D. (2006). Influence of long-term application of organic and inorganic fertilizer to build up soil fertility and nutrient uptake in mintmustard cropping sequence. CSOSA, $37: 63-76$.

[20] Dutta, S.; Pal, R.; Chakeraborty, A.; Chakrabarti, K. (2003). Influence of integrated plant nutrient phosphorus and sugarcane and sugar yields. Field Crops Res., 77 : 43-49.

[21] Bokhtiar, S.M., Sakurai, K. (2005). Effects of organic manure and chemical fertilizer on soil fertility and productivity of plant and ratoon crops of sugarcane. Arch. Agro. Soil Sci., $51: 325-334$.

[22] Nacro, S.R. (2018). Effets des fertilisants organiques sur la production de la tomate et les paramètres chimiques du sol au centre nord du Burkina Faso, mémoire d'Ingénieur du développement rural, Option : Agronomie. Université Nazi Boni (UNB), Institut du Développement Rural, Bobo-Dioulasso, Burkina Faso, 56 pages.

[23] Sawadogo, A. (2017). Evaluation de différentes formulations de compost associé ou non aux Trichoderma et/ou au champignon mycorhizien arbusculaire (CMA) sur les proprieties chimiques et biologiques du sol et le rendement du chou (Brassica oleracea L.), mémoire de fin de cycle en Vulgarisation Agricole, Université Nazi Boni (UNB), 85 pages.

[24] Tougouma, W.S.R., (2006). Effet de la fertilisation organique et minérale sur la production en biomasse et en huile essentielle de la citronnelle (Cymbopogon citratus (D.C) Stapf), mémoire du diplôme d'ingénieur du développement rural Option : Agronomie. Université Polytechnique de Bobo, Institut du Développement Rural, BoboDioulasso, Burkina Faso, 71 pages.

[25] Ayinla, A.; Alagbe, I.A.; Olayinka, B.U.; Lawal, A.R.; Aboyeji, O.O ; Etejere, E.O. (2018). Effects of organic, inorganic and organo-mineral fertilizer on the growth, yield and nutrient composition of Corchorus Olitorious (L), Ceylon J. Sci. 47(1) : 13-19.

[26] Nyembo, K.L.; Useni, S.Y.; Mpundu, M.; Bugeme, M.D.; Kasongo, L.E.; Baboy, L. (2012). Effet des apports des doses variées de fertilisants inorganique (NPK et Urée) sur 
le rendement et la rentabilité économique de nouvelles variétés de Zea mays, $L$. à Lubumbashi, Sud-Est de la RD Congo, J. Appl. Biosci. 59: 4286-4296.

[27] Seh, N.; Emmanuel, E. (2009). Impacts agronomiques, economiques et environnementaux de quelques amendements organiques à Nkolondom (YaoundéCameroun), mémoire de fin de cycle en Etudes d'Impacts Environnementaux (EIE), Université de dschang faculté d'agronomie et des sciences agricoles, 116 pages.

[28] Guiatin, E. (2015). Option de fertilisation pour la production durable de mil et de sorgho parcs agroforestier du centre sud au Burkina Faso, mémoire d'ingénieure de développement rural, IDR/UPB, Burkina Faso, 227 pages.

[29] Kitabala, M.A.; Tshala, U.; Kalenda, M.A.; Tshijika, I.M.; Mufind, K.M. (2016). « Effets de différentes doses de compost sur la production et la rentabilité de la tomate (Lycopersicon Esculentum Mill) dans la ville de Kolwezi province du Lualaba (RD Congo) », J. Appl. Biosci., 102(1) : 9669-9679.

[30] Mankoussou, M.; Mialoundama, F.; Diamouangana, J. (2017). Evaluation économique de quelques niveaux de fertilisation du maïs (Zea mays L. variété Espoir) dans la vallée du Niari, République du congo, J. Appl. Biosci., 111 (1): 10894-10904. 